\section{INQUIRY-BASED SCIENCE EDUCATION AS A REVISION STRATEGY}

\author{
Ivana Sotáková, \\ Mária Ganajová, \\ Mária Babinčáková
}

\section{Introduction}

In the recent decades, it is recommended to use active inquiry methods in teaching and learning science. Inquiry, investigation, application of knowledge in new situations and on new problems and solutions are the best methods for students to develop their cognitive processes and performance skills (Pellegrino \& Hilton, 2012).

An effective strategy is to implement Inquiry-Based Science Education (IBSE) in teaching as well as learning (Anderson, 2007; Brickman et al., 2009; Bruder \& Prescott, 2013; Furtak et al., 2012; Harlen 2013; Krajcik et al., 2001; Minner et al., 2010; Rocard et al., 2007; Sadeh \& Zion, 2009; Schroeder et al., 2007; Wilcox et al., 2015).

According to multiple researchers, IBSE is based on the constructivist approach (Eisenkraft, 2003; Llewellyn, 2002; White \& Frederiksen, 1998). One of the models emphasizing the constructivist principles is the $5 \mathrm{E}$ Educational Model consisting of 5 phases: Engage, Explore, Explain, Elaborate, and Evaluate (Bybee et al., 2006).

From the students' viewpoint, inquiry is an active approach to learning that includes investigation of the surrounding world, which prompts the formulation of questions, discovering, and testing the findings to achieve deeper understanding. During the process, students collect and record information which they subsequently present in different ways; they also work with other information sources (books, videos, Internet), and communicate with others (peers, teacher, experts, etc.). Drawing meaningful conclusions requires reflection, discussion, comparison of findings with others, interpreting obtained information, and application of new knowledge in different contexts (Ash \& Kluger-Bell, 2000). In IBSE, the teacher changes from an authority/leader to a guide (Windschitl, 2002).

Researchers have specified several different levels of inquiry based on the amount of information provided to the students (e.g. helping questions, instruction on the investigation procedure, instruction for data processing, etc.) or how much the teacher governs the activity and helps the students (e.g. asking questions, commenting, instructing, etc.) (Banchi \& Bell 2008; Bell
Abstract: The research aim was to identify the effect of revising the thematic unit "Changes in Chemical Reactions" using IBSE (based on confirmation inquiry) in the 8th grade of secondary school. This thematic unit is taught in chemistry lessons in the 2nd term of the 7th grade. A set of activities verified by a piece of pilot research was used to implement IBSE based on confirmation inquiry using the $5 E$ Educational Model. The research was performed in ten Slovak secondary schools during the 1st term of the 2017/2018 school year. This research employed the quasi-experimental methodology involving pre-test-post-test two-group design. The research sample consisted of 2928 th grade students. They were divided randomly into a control ( $n=149)$ and experimental $(n=143)$ group, and the intervention took place during 10 lessons. Cognitive tests based on the revised Bloom's taxonomy were used to measure students' knowledge and skills before and after revision. The results indicate that using IBSE (based on confirmation inquiry) in the revision phase is more effective than teaching without using IBSE in terms of developing conceptual understanding. It affects the lower and higher cognitive processes (understanding, application, and analysis) and stimulates learning mainly in students with lower academic performance.

Keywords: chemistry education, cognitive processes, confirmation inquiry, secondary school.

Ivana Sotáková, Mária Ganajová Pavol Jozef Šafárik University in Košice, Slovakia

Mária Babinčáková Pavol Jozef Šafárik University in Košice, Slovakia

Charles University in Prague, Czech Republic 
et al., 2005; Buck et al., 2008; Fradd et al., 2001; Rezba et al., 1999; Walker, 2007). For example, the 5-level inquiry model (Table 1) designed in the ESTABLISH project (European Science and Technology in Action: Building Links with Industry, Schools and Home).

Table 1

Inquiry levels as proposed in the ESTABLISH project (ESTABLISH, 2010)

\begin{tabular}{|c|c|c|c|c|c|}
\hline Inquiry level & $\begin{array}{c}\text { Question } \\
\text { (problem)? }\end{array}$ & $\begin{array}{l}\text { Methods } \\
\text { (solutions)? }\end{array}$ & $\begin{array}{c}\text { Result } \\
\text { (conclusion)? }\end{array}$ & & \\
\hline $\begin{array}{l}\text { Interactive discussion/demonstration } \\
\text { The teacher asks questions in an interactive way and leads student } \\
\text { discussion or asks questions and requires students to answer, explain } \\
\text { and provide evidence obtained by experimenting. }\end{array}$ & $x$ & $x$ & $x$ & 흑 & 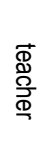 \\
\hline $\begin{array}{l}\text { Guided discovery (confirmation inquiry) } \\
\text { Students confirm (verify) a law (knowledge, connections) through an } \\
\text { activity whose result they already know. }\end{array}$ & $x$ & $x$ & $x$ & \multirow{3}{*}{ 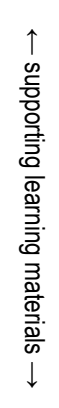 } & \multirow{3}{*}{ 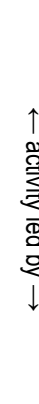 } \\
\hline $\begin{array}{l}\text { Guided inquiry } \\
\text { Students solve a problem formulated by the teacher using a procedure } \\
\text { prepared in advance, but they do now know the result. }\end{array}$ & $x$ & $x$ & & & \\
\hline $\begin{array}{l}\text { Bounded inquiry } \\
\text { Students solve a problem formulated by the teacher using a procedure } \\
\text { they prepare (design) on their own. }\end{array}$ & $x$ & & & & \\
\hline $\begin{array}{l}\text { Open inquiry } \\
\text { Students solve a problem they formulate on their own based on a proce- } \\
\text { dure they prepare (design) on their own. }\end{array}$ & & & & $\bar{\Sigma}$ & 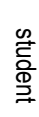 \\
\hline
\end{tabular}

The research of IBSE implementation in teaching and learning has proven the effect of IBSE in developing conceptual understanding (Kirschner et al., 2006; Laksana et al., 2019; Marshall \& Horton, 2011; Minner et al., 2010; Schroeder et al., 2007), problem-solving abilities in students (Prince \& Felder, 2007), developing critical thinking (Aksela, 2010; Baker et al., 2008), developing cognitive and scientific skills (Barron \& Darling-Hammond, 2008; Brickman et al., 2009; Kirschner et al., 2006; Lederman et al., 2014; McLoughlin et al., 2012), promoting motivation and interest (Rocard et al., 2007; Škoda et al., 2015; Wang et al., 2015), and developing positive attitudes to science (Hattie, 2009; Llewellyn, 2013). IBSE allows for better understanding of the scientific procedures and develops scientific literacy (Bass et al., 2009; Goodrum \& Rennie, 2007; Harlen, 2004; Marshall \& Alston, 2014; Marshall et al., 2016; Minner et al., 2010). It is suitable for all types of students: low as well as high performing ones (including the gifted students), boys and girls, all age groups (Trna et al., 2012).

However, there are also studies that have shown no significant influence of IBSE on students'learning process or their learning outcomes (Chang \& Mao, 1999; Schneider et al., 2002; Von Secker \& Lissitz, 1999) no improvement in terms of understanding natural phenomena (Khisfe \& AbdEl-Khalick, 2002) or enhanced understanding of scientific procedures (Berg et al., 2003; Klahr \& Nigam, 2004).

The ambiguous results of research comparing IBSE with other teaching methods may result from the fact that often, teaching methods used in the control groups have not been clearly defined, merely referred to as "traditional teaching methods" with no further specification, or there has been no control group at all.

\section{Research Problem}

The main aim of science education in Slovakia is to develop science literacy and capabilities necessary for future scientific work (ŠPÚ, 2014). The individual cycles of the OECD PISA international comparative assessment (Programme for International Student Assessment) have been pointing out since 2003 that Slovak students' performance in scientific literacy are below the OECD average (OECD, 2019). Slovak students understand and remember what they are taught in science lessons, however they fall behind their peers in other OECD countries in terms of higher-order cognitive processes such as application, analysis, assessment, and creativity. They have difficulties 
with independent reflecting on science phenomena and connections, assessing and formulating hypotheses, searching for and proposing solutions, interpreting the obtained data, drawing conclusions, and supporting their arguments with evidence (Miklovičová et al., 2017). Slovak students are acquiring knowledge and skills on the lower cognitive process level when the traditional lecture-based model is used. Can their knowledge and skills be enhanced through IBSE-based revision? In many studies, IBSE strategies have been implemented into teaching and learning to present the learning content in an accessible way (acquisition of knowledge and skills) on the given level of education (ISCED) in the respective year as provided in the educational standards. Many teachers believe that revision can be performed using different conditions and situations to enhance students' knowledge and skills (Kang, 2016; Montessori, 2017; Petlák, 2004).

\section{Research Aim and Research Questions}

The aim of the presented research was to identify the effect of revising the thematic unit "Changes in Chemical Reactions" using IBSE (based on confirmation inquiry) in the 8th grade of secondary school. The learning outcomes in the revision with the implementation of IBSE were compared with the learning outcomes of teaching without using IBSE. Cognitive tests with items in different domains of the revised Bloom's taxonomy were used to measure the learning outcomes (knowledge and skills) - a pre-test was given before the revision and a post-test was given afterwards. The tests' results were compared, and the obtained data were processed to evaluate the effect of teaching methods.

The research questions were defined as follows:

1. How much does revision using IBSE (confirmation inquiry) affect students' conceptual understanding?

2. Which students, in terms of academic performance, benefit from revision using IBSE?

\section{Research Hypotheses}

The research hypotheses verified within the research reflect the above-mentioned main research aim. The following hypotheses were formulated and tested:

$\mathrm{H}_{01}$ : Before the revision, the knowledge and skills of the experimental group and the control group are the same.

$\mathrm{H}_{02}$ : After the revision, the knowledge and skills of the experimental group and the control group are the same.

$\mathrm{H}_{03}$ : After the revision, the knowledge and skills of the experimental group and the control group in the cognitive process categories (remember, understand, apply, and analyse) are the same.

$\mathrm{H}_{04}$ : Before and after the revision, the knowledge and skills of the experimental group in terms of academic performance are the same.

\section{Research Methodology}

\section{General Background}

Pre-test and post-test two-group design was employed in the research (Cook \& Campell, 1979). Within a specified period of time, an experimental intervention was performed within the experimental group while the control group remained unaffected. The teaching method as an independent variable was manipulated to identify its effect on the dependent variable (in this case, knowledge and skills). Both groups were tested using the same methods before and after the experiment.

The research was performed in the first term of the 2017/2018 school year - from September to mid-October. The research was conducted at ten secondary schools in five regions of Slovakia (Prešov, Košice, Trenčín, Trnava, and Žilina regions). The selection of schools and teachers was deliberate. All 11 teachers (all women with more than 10 years of experience) who participated in the research took the "Innovative Methods in Teaching Chemistry and the Development of Key Competences in Students" course at Pavol Jozef Šafárik University in Slovakia. The course consisted of 8 contact lectures and 2 e-learning distance lessons. The course included lectures during which the teachers learned about the IBSE theory and inquiry activities pertaining to general, inorganic, and organic chem- 
istry topics. Subsequently, the teachers performed selected inquiry activities themselves. In the distance lessons, the teachers designed inquiry activities for a selected topic.

\section{Ethical Considerations}

The participation of teachers and students in the research was voluntary. The participants were given an Information Sheet and a Consent Form in advance. Before the research began, they were informed about their role in the research, time schedule, and data publishing. Information about students was obtained from the teachers based on the written consent of their parents (legal guardians). For the purpose of statistical processing and evaluation of the data collected, all teachers and students were assigned identification codes to maintain their anonymity.

\section{Sample}

The research sample consisted of $2928^{\text {th }}$ grade students. 135 (46.2\%) participants were male and $157(53.8 \%)$ female. The students were aged 13-14. The experimental group consisted of $143(49 \%)$ students and the control group consisted of $149(51 \%)$ students. Table 2 summarizes the number and percentage of students based on genders and academic performance in chemistry at the end of the $7^{\text {th }}$ grade ( $1=$ great performance to $5=$ fail).

\section{Table 2}

Characteristics of the experimental and control group

\begin{tabular}{|c|c|c|c|c|c|}
\hline \multirow{2}{*}{ Variable } & & \multicolumn{2}{|c|}{$\begin{array}{c}\text { Experimental group } \\
n=143\end{array}$} & \multicolumn{2}{|c|}{$\begin{array}{c}\text { Control group } \\
n=149\end{array}$} \\
\hline & & $\begin{array}{l}\text { Number } \\
\text { of students }\end{array}$ & Percentage & $\begin{array}{l}\text { Number } \\
\text { of students }\end{array}$ & Percentage \\
\hline \multirow{2}{*}{ Gender } & Male & 63 & 44 & 72 & 48 \\
\hline & Female & 80 & 56 & 77 & 52 \\
\hline Total & & 143 & 100 & 149 & 100 \\
\hline \multirow{4}{*}{$\begin{array}{l}\text { Academic performance in } \\
\text { chemistry at the end of the } \\
7^{\text {th }} \text { grade }\end{array}$} & Students with grade 1 & 69 & 48.3 & 89 & 59.7 \\
\hline & Students with grade 2 & 39 & 27.3 & 38 & 25.5 \\
\hline & Students with grade 3 & 31 & 21.7 & 15 & 10.1 \\
\hline & Students with grade 4 & 4 & 2.7 & 7 & 4.7 \\
\hline Total & & 143 & 100 & 149 & 100 \\
\hline
\end{tabular}

\section{Content Area}

In Slovakia, secondary school students start learning chemistry as a separate subject in the $7^{\text {th }}$ grade (ISCED 2). The "Changes in Chemical Reactions" thematic unit is taught in the second term of the $7^{\text {th }}$ grade. The formal SA standard for "Changes in chemical reactions" covers (ŠPÚ, 2014):

- Content standards: thermal changes during chemical reactions (exothermic and endothermic reactions), rate of chemical reactions, examples of slow and quick reactions, factors affecting the rate of chemical reactions.

- Performance standards: provide real life examples of exothermic and endothermic reactions, perform experiments to measure thermal changes during chemical reactions, record the results in tables and interpret them, distinguish slow and quick reactions, perform and evaluate experiments investigating how different factors influence the rate of a chemical reaction.

In the 7th and 8th grades, there are two chemistry lessons per week/66 lessons per term. In the 8th grade, 10 lessons are designated to revise the learning content from the 7th grade. The curricula for teaching in the 7th grade and revising in the 8 th grade are identical. 


\section{Confirmation Inquiry Activities}

For the purpose of the "Changes in chemical reactions" thematic unit, a set of five inquiry activities was created within the National project "IT Academy - Education for the 21st Century". The activities were created according to the $5 \mathrm{E}$ Educational Model and focused on confirmation inquiry (second level of inquiry according to the hierarchy designed in the Establish project). Two lessons were designated for each inquiry activity. The inquiry activities are described in Appendix A.

The activities created were verified during a pilot research performed in the second term of the 2016/2017 school year; the sample consisted of 450 students taught by 25 teachers. The design-based research (DBR) methodology was used in this research. Based on the research results, the activities were optimised (Sotáková et al., 2020).

\section{Characteristics of Confirmation Inquiry Activities}

In confirmation inquiry activities students worked in pairs or groups of 3-4. First, students learned about the problem from a worksheet (based on the 5E Model): e.g. how crushing of a sodium bicarbonate tablet affects its reaction with vinegar. Students' task was to formulate their assumptions about the expected outcome. Subsequently, students verified their assumptions in practice, formulated their explanations (based on the experiment) and recorded them in the worksheets. In the phase of knowledge and skill enhancement, students applied them in new, real-life situations (e.g. correct fire setting methods, proper chewing of food, limescale removal). In course of the lesson, the teacher guided the students by asking suitable questions.

As an example, "The Effect of Temperature on the Rate of Chemical Reactions" inquiry activity was selected for demonstration (Table 3). The aim of this activity was to perform and evaluate an experiment to verify how temperature affects the rate of chemical reaction between vinegar and sodium bicarbonate.

\section{Table 3}

"The Effect of Temperature on the Rate of Chemical Reactions" inquiry activity

\section{Engage}

In this phase, the teacher tries to engage the students and motivate them to investigate the presented phenomenon. They ask questions such as:

1. What are the properties of vinegar and what is it used for?

2. What are the properties of sodium bicarbonate and what is it used for?

3. Do you know how vinegar and sodium bicarbonate react?

4. Which factors could affect how vinegar and sodium bicarbonate react?

In this phase, the teacher can examine students' knowledge and ideas to collect, record, and identify possible misconceptions.

\section{Explore}

The teacher divides students into pairs or groups of 3-4 and hands them worksheets.

Task 1: Try to estimate how the temperature of vinegar can influence the course of its reaction with sodium bicarbonate. Write down your assumptions.

Subsequently, students verify the effect of temperature on the course of this chemical reaction.

Task 2: Perform the experiment according to instructions.

Since students will perform the experiment on their own according to the instructions, it is necessary to warn them about the safe use of chemicals and laboratory instruments. The teacher prepares the instruments and chemicals in advance according to the number of student pairs or groups. Instruments: 3 identical volumetric flasks (100 ml), 2 graduated cylinders $(50 \mathrm{ml}), 2$ beakers $(400 \mathrm{ml}), 3$ identically sized balloons, funnel, spatula, filtration paper, scales

Chemicals: vinegar, sodium bicarbonate, water

Students perform the experiment to observe the reaction of vinegar and sodium bicarbonate using simple apparatus (flask with a balloon on its neck) at different temperatures (one $400 \mathrm{ml}$ beaker is half-filled with cold water and the other with warm water). The ambient temperature will be used for comparison.

Note: Flasks with vinegar need to be dipped in cold and warm water respectively before the reaction - so that the difference between the rate of chemical reactions is visible. 


\footnotetext{
Explain

In this phase, the teacher aims to confront students' results with their knowledge and possible misconceptions identified in the previous phase.

Task 3: Answer the following questions.

1. Write down what you observed 10 seconds after pouring sodium bicarbonate into vinegar.

2. In Figure 1, mark the course of the reaction in the banks dipped in cold and warm water respectively to clearly show, which reaction was quicker.

3. Correct the statements (cross out what is incorrect).

In the flask dipped in cold water more/fewer bubbles were produced and the rate of reaction was higher/lower.

In the flask dipped in warm water more/fewer bubbles were produced and the rate of reaction was higher/lower.

4. Write down which balloon was blown up more quickly.

5. Write down the name of the gas that blew up the balloons.

6. Did crushing the sodium bicarbonate tablet the reaction rate?

7. Write whether the higher temperature of the vinegar increased or decreased the rate of this reaction.

Task 4: Discuss in your group and explain how the change of temperature affects the rate of
} chemical reactions.

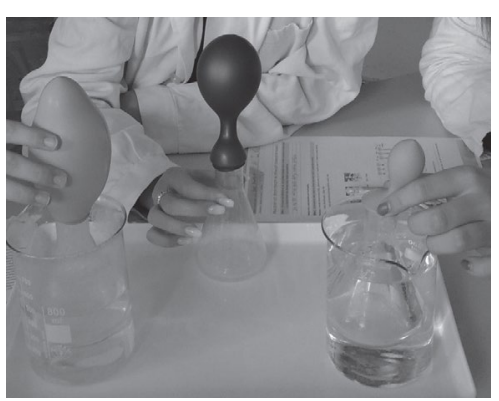

\section{Figure 1}

The effect of temperature on the reaction rate between vinegar and sodium bicarbonate

\section{Elaborate}

Task 5A: Provide examples of other substances whose reaction with vinegar you would like to see.

(Examples: reaction of vinegar with egg shells, chalk or mussel).

Task 5B: Discuss in your group, then answer the following questions.

1. Why do we keep food in a fridge or freezer?

2. Why does food cook sooner in a pressure cooker than in a normal pan?

\section{Evaluate}

This phase focuses on formulating questions developing higher-order cognitive processes, thus helping students develop their skills, judge, evaluate, analyse, and interpret the results of their work.

Task 6: Students evaluate their own knowledge and skills by filling in the table focused on meta-cognition. In Table 3 they record the knowledge and skills learned on the occasion, in Table 2 they record the information they consider the most interesting, and in Table 1 they write a question whose answer they still do not know.

\section{Instrument}

\section{Tests}

Standardised cognitive tests were used as the research instrument for the pre-test and post-test (Rabčan et al., 2019). Both the pre-test and the post-test consisted of 10 items focusing on different domains of the revised Bloom's taxonomy (Anderson \& Krathwohl, 2001). The tests were comparable, they included the learning content of the "Changes in chemical reactions" thematic unit according to the content and performance standards defined in the formal SA standard (ŠPÚ, 2014). The items focused on the following categories of a) knowledge dimension: factual (1 item), conceptual (8 items) and procedural (1 item), and b) cognitive process dimension: remember (1 item), understand (4 items), apply (4 items), and analyse ( 1 item) (see Table 4). As for the task type, 5 items were single-choice questions and 5 were open questions with short answer. These items were developed and standardized by the National Institute for Certified Educational Measurements of Ministry of Education, Science, Research and Sport of Slovak Republic. Unfortunately, the database did not contain items pertaining to the "evaluate" and "create" domains. 


\section{Table 4}

Pre-test and post-test items based on the revised Bloom's taxonomy

\begin{tabular}{ccc}
\hline Item number & Category: knowledge dimension & Category: cognitive process dimension \\
\hline 1 & Conceptual & Remembering \\
2 & Conceptual & Understanding \\
3 & Conceptual & Understanding \\
4 & Conceptual & Understanding \\
5 & Procedural & Understanding \\
6 & Factual & Application \\
7 & Conceptual & Application \\
8 & Conceptual & Application \\
9 & Conceptual & Application \\
10 & Conceptual & Analysis \\
\hline
\end{tabular}

\section{Procedures}

Before the beginning of the research the teachers took a 20-question self-assessment survey (Holloway, 2015). The questionnaire consisted of questions assessing their use of IBSE in chemistry by means of five subscales focused on the 5E educational model (Engage, Explore, Explanation, Elaborate, Evaluate). Questions were rated on a 5-point Likert-type scale: $1=$ almost never, $2=$ rarely, $3=$ sometimes, $4=$ often, 5=very often. A high overall score indicated that IBSE was used frequently, while a low score indicated that the traditional lecture-based approach prevailed. All teachers achieved medium scores as they reported using the IBSE (5E Educational Model) at least $70 \%$ of the teaching time. The teachers for the research were selected deliberately to ensure comparable IBSE skills.

At the beginning of September 2018, all students took the pre-test. Its goal was to identify and compare their level of knowledge and skills in the "Changes in chemical reactions" thematic unit taught during the previous school year in the period from February to June 2018. The pre-test results showed that all classroom groups were at a statistically similar level $(p>.05)$. Therefore, the classroom groups were subsequently randomly assigned to either the control $(n=8)$ or experimental $(n=7)$ group.

After the pre-test, both groups proceeded to revise the "Changes in chemical reactions" thematic unit in the course of 10 lessons from September to mid-October 2018. In the experimental group, revision was performed using IBSE (confirmation inquiry) and in the control group IBSE was not used at all. In the experimental group revision was carried out using the five inquiry activities. Students worked in pairs or groups of 3-4; students with different academic performance were mixed. In the control group, teachers revised the topic using methods of their choice, e.g. questions \& answers, oral and written revision, textbook studying, demonstration experiments, laboratory work.

After 10 lessons focused on revising the "Changes in chemical reactions" thematic unit, all students were administered the post-test.

\section{Data Analysis}

Students' pre- and post-tests were evaluated. 1 point was awarded for each correct answer; 0 points were awarded for an incorrect answer; the maximum score was 10 points. Data were processed using Excel and analysed. The overall test score was analysed as well as specific scores for different cognitive process categories and individual items. The reliability of the tests results was calculated using the Cronbach's alpha (Cronbach, 1951) and equalled for the pre-test $(a=.693)$ and for the post-test $(a=.702)$. Also, normal distribution of the results was controlled for total scores, grouped items, and for each item separately, using the Kolmogorov-Smirnov test. The Kolmogorov-Smirnov test confirmed that the obtained data showed non-normal distribution $(p<.001)$, therefore the non-parametric Mann-Whitney $U$ test was used to compare the data of the control and experimental groups.

Statistical analyses were performed using SPSS version 18 (SPSS Inc., 2009). In all data analyses, the $p$ value $<.05$ was considered significant. 


\section{Research Results}

The Mann-Whitney $U$ test results for the pre-test and post-test can be seen in Tables 5 and 6 .

\section{Table 5}

The Mann-Whitney U test results in pre-test

\begin{tabular}{|c|c|c|c|c|c|c|c|c|}
\hline & \multirow{2}{*}{ Item } & \multicolumn{3}{|c|}{ Experimental group } & \multicolumn{3}{|c|}{ Control group } & \multirow{2}{*}{$p$} \\
\hline & & $\bar{x}$ & $M D$ & $S D$ & $\bar{x}$ & $M D$ & $S D$ & \\
\hline \multirow{10}{*}{$\begin{array}{c}\text { Items } \\
\text { separated }\end{array}$} & Item 1 & .66 & 1.00 & .472 & .69 & 1.00 & .477 & .344 \\
\hline & Item 2 & .37 & .00 & .483 & .39 & .00 & .487 & .393 \\
\hline & Item 3 & .18 & .00 & .386 & .19 & .00 & .389 & .464 \\
\hline & Item 4 & .29 & .00 & .452 & .32 & .00 & .466 & .301 \\
\hline & Item 5 & .90 & 1.00 & .306 & .90 & 1.00 & .310 & .476 \\
\hline & Item 6 & .87 & 1.00 & .339 & .85 & 1.00 & .335 & .374 \\
\hline & Item 7 & .46 & .00 & .499 & .45 & .00 & .497 & .433 \\
\hline & Item 8 & .37 & .00 & .483 & .35 & .00 & .488 & .413 \\
\hline & Item 9 & .67 & 1.00 & .470 & .66 & 1.00 & .468 & .500 \\
\hline & Item 10 & .38 & .00 & .485 & .40 & .00 & .490 & .356 \\
\hline \multirow{5}{*}{$\begin{array}{c}\text { Items } \\
\text { grouped }\end{array}$} & Remembering & .66 & 1.00 & .472 & .69 & 1.00 & .477 & .344 \\
\hline & Understanding & .59 & 1.00 & .491 & .58 & 1.00 & .495 & .448 \\
\hline & Application & .43 & .00 & .496 & .45 & .00 & .498 & .404 \\
\hline & Analysis & .38 & .00 & .485 & .40 & .00 & .490 & .356 \\
\hline & Entire test & .51 & 1.00 & .500 & .53 & 1.00 & .504 & .412 \\
\hline
\end{tabular}

It can be seen that the mean success rate in the experimental and control group is comparable in Table 5. The $\mathrm{H}_{01}$ hypothesis was formulated and tested to verify this assumption.

\section{Table 6}

The Mann-Whitney U test results in post-test

\begin{tabular}{|c|c|c|c|c|c|c|c|c|}
\hline & \multirow{2}{*}{ Item } & \multicolumn{3}{|c|}{ Experimental group } & \multicolumn{3}{|c|}{ Control group } & \multirow{2}{*}{$p$} \\
\hline & & $\bar{x}$ & $M D$ & $S D$ & $\bar{x}$ & $M D$ & $S D$ & \\
\hline \multirow{10}{*}{$\begin{array}{c}\text { Items } \\
\text { separated }\end{array}$} & Item 1 & .46 & .00 & .498 & .41 & .00 & .492 & .251 \\
\hline & Item 2 & .74 & 1.00 & .438 & .62 & 1.00 & .484 & .041 \\
\hline & Item 3 & .88 & 1.00 & .324 & .93 & 1.00 & .250 & .223 \\
\hline & Item 4 & .77 & 1.00 & .421 & .78 & 1.00 & .415 & .444 \\
\hline & Item 5 & .71 & 1.00 & .455 & .46 & .00 & .499 & .001 \\
\hline & Item 6 & .68 & 1.00 & .467 & .40 & .00 & .490 & .001 \\
\hline & Item 7 & .96 & 1.00 & .200 & .91 & 1.00 & .282 & .251 \\
\hline & Item 8 & .82 & 1.00 & .386 & .57 & 1.00 & .495 & .001 \\
\hline & Item 9 & .29 & .00 & .455 & .17 & .00 & .380 & .039 \\
\hline & Item 10 & .92 & 1.00 & .266 & .71 & 1.00 & .453 & .001 \\
\hline
\end{tabular}




\begin{tabular}{|c|c|c|c|c|c|c|c|c|}
\hline & \multirow{2}{*}{ Item } & \multicolumn{3}{|c|}{ Experimental group } & \multicolumn{3}{|c|}{ Control group } & \multirow{2}{*}{$p$} \\
\hline & & $\bar{x}$ & $M D$ & $S D$ & $\bar{x}$ & $M D$ & $S D$ & \\
\hline \multirow{5}{*}{$\begin{array}{l}\text { Items } \\
\text { grouped }\end{array}$} & Remembering & .46 & .00 & .498 & .41 & .00 & .492 & .251 \\
\hline & Understanding & .77 & 1.00 & .418 & .68 & 1.00 & .458 & .001 \\
\hline & Application & .69 & 1.00 & .464 & .52 & 1.00 & .498 & .001 \\
\hline & Analysis & .92 & 1.00 & .266 & .71 & 1.00 & .453 & .001 \\
\hline & Entire test & .71 & 1.00 & .448 & .58 & 1.00 & .490 & .001 \\
\hline
\end{tabular}

In Table 6, it can be seen that the experimental group scored higher in the post-test than the control group. As for the cognitive process dimension measured by the post-test, the EG scored higher than the CG in all categories observed.

A comparison of pre- and post-test results in the EG listed according to the academic performance of respective students (Table 2 ) indicated that revising the learning content using IBSE (confirmation inquiry) was effective.

Hypotheses $\mathrm{H}_{02}$ to $\mathrm{H}_{04}$ were formulated and tested to verify these assumptions.

\section{Hypothesis Testing}

The criteria for decision making in Mann-Whitney's $U$ test are as follows: if $p>.05, \mathrm{H}_{0}$ is accepted; if $p<.05, \mathrm{H}_{0}$ is rejected. The Mann-Whitney $U$ test results for hypothesis testing can be seen in Table 7 .

Table 7

Statistic verification of research hypotheses - results

\begin{tabular}{|c|c|c|c|c|c|}
\hline & Hypothesis & $z$ & $p$ & Description & Conclusion \\
\hline H01 & & -.668 & .412 & Accepted & There is no significant difference \\
\hline $\mathrm{H} 02$ & & -6.095 & .001 & Rejected & There is a significant difference \\
\hline \multirow{4}{*}{$\mathrm{H} 03$} & Remembering & -.331 & .251 & Accepted & There is no significant difference \\
\hline & Understanding & -2.410 & .001 & Rejected & There is a significant difference \\
\hline & Analysis & -6.353 & .001 & Rejected & There is a significant difference \\
\hline & Application & -4.012 & .001 & Rejected & There is a significant difference \\
\hline \multirow{3}{*}{ H04 } & $\begin{array}{l}\text { Students who achieved grade } 1 \text { in } \\
\text { chemistry previous year }\end{array}$ & -4.388 & .001 & Rejected & There is a significant difference \\
\hline & $\begin{array}{l}\text { Students who achieved grade } 2 \text { in } \\
\text { chemistry previous year }\end{array}$ & -4.758 & .001 & Rejected & There is a significant difference \\
\hline & $\begin{array}{l}\text { Students who achieved grades } 3 \text { or } 4 \\
\text { in chemistry previous year }\end{array}$ & -5.726 & .001 & Rejected & There is a significant difference \\
\hline
\end{tabular}

\footnotetext{
${ }^{*}$ Level of significance $=.05$.
}

\section{Discussion}

At the beginning of revision in September 2018, a pre-test was administered to identify the actual effect of the traditional lecture-based teaching model used previously, from February to June 2018. In the pre-test, students scored higher in remembering and understanding, but lower in the higher-order cognitive processes such as application and analysis (see Table 5). These results were comparable with Slovak students' results in the PISA 2018 international comparison measuring science literacy (OECD, 2019). 
The question was whether revising using IBSE could affect the results.

Therefore, an experiment was performed to compare the learning outcomes produced by using two different teaching methods - teaching with and without using IBSE (based on confirmation inquiry) during 10 lessons. In both groups, learning outcomes were measured using a post-test. The data obtained this way were processed to evaluate and summarise the effect of teaching methods.

1. The findings indicate that in the revision phase, the implementation of IBSE (confirmation inquiry) was more effective than teaching without using IBSE in terms of developing conceptual understanding. It was confirmed by the post-test results in which the experimental group scored better than the control group and the difference was statistically significant $(p<.001)$ (see Tables 6 and 7). This result is consistent with the research results confirming the effect of IBSE strategies on improving students' conceptual understanding (Blanchard et al., 2010; Kireš et al., 2016; Kirschner et al., 2006; Minner et al., 2010; Nieswandt, 2007; Prince \& Felder, 2007; Sever \& Güven, 2014). The results in the cognitive process, application, and analysis show that IBSE helps develop higher-order cognitive skills (HOCS). This result relates to the fact that IBSE supports HOCS by using questions, critical thinking, and problem-solving (Anderson, 2002; Oliviera, 2010; Lemlech, 1998; Zoller, 2011).

2. According to the post-test results, the experimental group scored statistically better in the three analysed cognitive process categories: understanding, application, and analysis (see Tables 6 and 7). It relates to the fact that deeper understanding of the learning content is achieved when students learn actively (Piaget, 1973). However, no statistically significant difference between experimental and control groups was confirmed in the category of remembering. It has to do with the fact that in Slovakia, teaching aimed at remembering is preferred, which is consistent with the PISA results of 2006-2018 (OECD, 2019). These findings indicate that using IBSE to revise in teaching and learning can help Slovak students develop HOCS, which is a way to also improve their results in PISA testing.

3. Students worked in pairs or groups of 3-4; students with different academic performance were mixed to learn from each other so that higher-achieving students helped their peers who learned from them. For students who tend to be less active in front of the whole class, group work represents an opportunity to participate. The biggest statistical difference in the levels of knowledge and skills before and after the revision was identified in students with lower academic performance (grade 3-4) in the experimental group (see Table 7). These findings are consistent with the outcomes of studies confirming the influence of IBSE on academic performance (Berg et al., 2003; Pandey et al., 2011; Witt \& Ulmer, 2010).

The results obtained may have been influenced by the following:

Activities verified during the pilot research and subsequently optimised were used in the revision phase (Sotáková et al., 2020).

Students in the EG obtained knowledge and skills by means of laboratory work included in the activities. It represents a suitable form of teaching in terms of IBSE application (Abrahams \& Millar, 2008; Hofstein et al., 2005; Högström et al., 2010; Millar \& Abrahams, 2009) as interconnecting inquiry activities with practical tasks provides a great potential to develop skills, abilities, and also scientific thinking in students.

The implementation of confirmation inquiry into teaching students in this age group may also have influenced the research results. However, the published research works have not clearly confirmed whether confirmation inquiry in teaching is effective, see e.g. Blanchard et al. (2010) who have identified significantly better post-test results in students taught using guided inquiry in comparison to students taught using confirmation inquiry. Similarly, to Lederman et al. (2008) the aforementioned research team has recommended to combine confirmation and guided inquiry. However, in this research, IBSE was used to teach secondary school students who are still considered beginners at learning, therefore they should have access to direct instructions clarifying the concepts and work procedures required by the respective subject (Clements \& Battista, 1990; Mayer, 2004) - which is the goal of confirmation inquiry (Bruck et al., 2008; National Research Council, 2000; Rezba et al., 1999).

If a teacher does not have access to ready-made, verified activities, or if they have little experience in IBSE, the differences may not be that significant. As supported by research results, developing IBSE teaching skills is not easy for teachers either (Capps \& Crawford, 2013; Colburn, 2000; Wallace \& Kang, 2004).

The limits of using IBSE in teaching include insufficient explanation of IBSE in curricula-related documents, teachers' training in using IBSE or lack of time necessary to perform inquiry activities, and insufficient practical equipment in schools. In this research, these problems were eliminated by using verified activities that took into account the necessary amount of time (2 lessons), commonly available tools and chemicals. Further limits of this 
research included the available sample of secondary school 8-graders, the difficulty of the "Changes in chemical reactions" thematic unit, and a relatively short implementation period of IBSE into teaching.

The activities designed for the "Changes in chemical reactions" thematic unit are high quality as confirmed by the fact that they were included in the methodology guide for teaching chemistry in the 7th grade of secondary schools and 2th year of 8-year grammar schools (Vicenová \& Ganajová, 2019). This manual was published with a recommendation clause from the Scientific Grant Agency of the Ministry of Education, Science, Research and Sport of the Slovak Republic. Most Slovak teachers working at secondary and 8-year grammar schools use it in teaching.

\section{Conclusions and Implications}

The presented research aimed to identify the effect of IBSE implementation (confirmation inquiry) in learning content revision on the development of conceptual understanding. Until now, no pedagogical research focused on using IBSE in revision has been published.

The findings indicate that in the revision phase, the implementation of IBSE (confirmation inquiry) was more effective than teaching without using IBSE in terms of developing conceptual understanding. A detailed analysis of the items tested showed that implementing IBSE (confirmation inquiry) helped develop the higher-order cognitive processes such as application and analysis. The statistical analysis also showed that the investigated differences were statistically significant. The implementation of IBSE (confirmation inquiry) stimulated learning mainly in students with lower academic performance (i.e. students with grades 3-4). IBSE helped these students develop conceptual understanding in the most pronounced way.

The research results confirmed the effect of using confirmation inquiry to revise and enhance understanding of the given topic in younger students.

Indirectly, it confirms that future teachers should be trained in IBSE application; before this idea is implemented in teacher training provision of quality ready-made activities could help. Slovakia.

The aforementioned findings suggest new tasks for the creators of educational policies and teachers in

Although in Slovakia, concepts such as "increasing the quality of upbringing and education", "increasing the availability of quality education and upbringing", or "modernisation of education and upbringing" are widely referred to, the actual practice is at a standstill. The requirement to implement IBSE is stipulated in the state educational programmes in Slovakia, but its application in educational practice is very slow, mainly due to the inertia of the educational system.

The creators of the educational programmes should initiate specific changes to the state educational programmes and offer specific verified activities in the respective methodology guidelines to provide teachers with guidance. Moreover, these activities should be accessible in the digital form in a central digital storage with free licences, the development of which has been contemplated in Slovakia for some time.

Last but not least, continuous specialised and methodological support for (future) teachers must be provided to help them select and adapt the learning contents and create school educational programmes. This way, students would be exposed to the long-term and complex impact of IBSE.

\section{Acknowledgements}

This research was supported by the grants VEGA No. 1/0265/17 "Formative Assessment in Natural Sciences, Mathematics and Informatics" and KEGA No. 004UPJŠ-4/2020 "Creation, Imple-mentation, and Verification of the Effectiveness of Digital Library with the Formative Assessment Tools for the Natural Sciences, Mathematics and Informatics at the Elementary School".

\section{References}

Abrahams, I., \& Millar, R. (2008). Does practical work really work? A study of the effectiveness of practical work as a teaching and learning method in school science. International Journal of Science Education, 30(14), 1945-1969. https://doi. org/10.1080/09500690701749305

Aksela, M. K. (2010). Evidence-based teacher education: Becoming a lifelong research-oriented chemistry teacher? Chemistry Education Research and Practice, 11(2), 84-91. https://doi.org/10.1039/C005350N

Anderson, R. D. (2002). Reforming science teaching: What research says about inquiry. Journal of Science Teacher Education, 13(1), 1-12. https://doi.org/10.1023/A:1015171124982

Anderson, R. D. (2007). Inquiry as an organizing theme for science curricula. In S. K. Abell \& N. G. Lederman (Eds.), Handbook of Research on Science Education (pp. 807-830). Lawrence Erlbaum Associates. 
Anderson, L. W., \& Krathwohl, D. R. (2001). A taxonomy for learning, teaching, and assessing: A revision of Bloom's taxonomy of educational objectives. https://www.uky.edu/ rsand1/china2018/texts/Anderson-Krathwohl\%20-\%20A\%20taxonomy\%20 for\%20learning\%20teaching\%20and\%20assessing.pdf

Ash, D., \& Kluger-Bell, B. (1999). Identifying inquiry in the K-5 classroom. In Foundations Volume II: A monograph for professionals in science, mathematics, and technology education: Inquiry, thoughts, views, and strategies for the K-5 classroom (pp. 79-85). National Science Foundation.

Baker, W., Barstack, R., Clark, D., Hull, E., Goodman, B., Kook, J., Kraft, K., Ramakrishna, P., Roberts, E., Shaw, J., Weaver, D., \& Lang, M. (2008). Writing-to-learn in the inquiry-science classroom: Effective strategies from middle school science and writing teachers. The Clearing House: A Journal of Educational Strategies, Issues and Ideas, 81(3), 105-108. https://doi.org/10.3200/ TCHS.81.3.105-108

Banchi, H., \& Bell, R. (2008). The many levels of inquiry. Science and Children, 46(2), 26-29.

Barron, B., \& Darling-Hammond, L. (2008). Teaching for meaningful learning: A review of research on inquiry-based and cooperative learning. In L. Darling-Hammond, B. Barron, P. D. Pearson, A. H. Schoenfeld, E. K. Stage, T. D. Zimmerman, G. N. Cervetti, \& J. L. Tilson (Eds.), Powerful learning: What we know about teaching for understanding (pp. 11-70). Jossey-Bass/John Wiley \& Sons.

Bass, J. E., Contant, L. T., \& Carin, A. A. (2009). Teaching science as inquiry (11th ed.). Allyn \& Bacon.

Bell, R. L., Smetana, L., \& Binns, I. (2005). Simplifying inquiry instruction. The Science Teacher, 72(5), 30-33.

Berg, C. A. R., Bergendahl, V. C. B., Lundberg, B. K. S., \& Tibell, L. A. E. (2003). Research report: Benefiting from an open-ended experiment? A comparison of attitudes to, and outcomes of, an expository versus an open-inquiry version of the same experiment. International Journal of Science Education, 25(3), 351-372. https://doi.org/10.1080/09500690210145738

Blanchard, M. R., Southerland, S. A., Osborne, J. W., Sampson, V. D., Annetta, L. A., \& Granger, E. M. (2010). Is inquiry possible in light of accountability? A quantitative comparison of the relative effectiveness of guided inquiry and verification laboratory instruction. Science Education, 94(4), 577-616. https://doi.org/10.1002/sce.20390

Brickman, P., Gormally, C., Hallar, B., \& Armstrong, N. (2009). Effects of inquiry-based learning on students' science literacy skills and confidence. International Journal for the Scholarship of Teaching and Learning, 3(2), 1-22. https://doi.org/10.20429/ ijsotl.2009.030216

Bruck, L. B., Bretz, S. L., \& Towns, M. H. (2008). Characterizing the level of inquiry in the undergraduate laboratory. Journal of College Science Teaching, 38(1), 52-58.

Bruder, R., \& Prescott, A. (2013). Research evidence on the benefits of IBL. ZDM - The International Journal on Mathematics Education (Zentralblatt für Didaktik der Mathematik), 45(6), 811-822. https://doi.org/10.1007/s11858-013-0542-2

Bybee, R. W., Taylor, J. A., Gardner, A., Van Scotter, P., Carlson Powell, J., Westbrook, A., \& Landes, N. (2006). The BSCS 5 E instructional model: Origins, effectiveness and applications. BSCS.

Capps, D. K., \& Crawford, B. A. (2013). Inquiry-Based Professional Development: What does it take to support teachers in learning about inquiry and nature of science? International Journal of Science Education, 24(3), 497-526. https://doi.org/10.1080 /09500693.2012.760209

Clements, D. H., \& Battista, M. T. (1990). Constructivist learning and teaching. Arithmetic Teacher, 38(1), 34-35.

Colburn, A. (2000). An inquiry primer. Science Scope, 23(6), $42-44$.

Cook, T. D., \& Campbell, D. T. (1979). Quasi-experimentation: Design and analysis issues for field settings. Rand McNally.

Cronbach, L. J. (1951). Coefficient alpha and the internal structure of tests. Psychometrika, 16(3), 297-334. https://doi.org/10.1007/ BF02310555

Eisenkraft, A. (2003). Expanding the 5E model: A proposed 7E model emphasizes "transfer of learning" and the importance of eliciting prior understanding (Teacher Practitioner). The Science Teacher, 70(6), 56-59.

Establish (2011). Guide for developing ESTABLISH Teaching and Learning Units. ESTABLISH project. http://www.establish-fp7. eu/sites/default/files/general/ESTABLISH_D3-4_GUIDE_UNITS_0.pdf.

Fradd, S. H., Lee, O., Sutman, F. X., \& Saxton, M. K. (2001). Promoting science literacy with English language learners through instructional materials: A case study. Bilingual Research Journal, 25(4), 479-501. https://doi.org/10.1080/15235882.2001.11074464

Furtak, E. M., Seidel, T., Iverson, H., \& Briggs, D. C. (2012). Experimental and quasi-experimental studies of inquiry-based science teaching: A meta-analysis. Review of Educational Research, 82(3), 300-329. https://doi.org/10.3102/0034654312457206

Goodrum, D., \& Rennie, L. (2007). Australian school science education national action plan 2008 - 2012 Volume 1: The national action plan. Australian Government Department of Education, Science and Training. https://files.eric.ed.gov/fulltext/ ED511041.pdf

Harlen, W. (2004). Talking and writing: have we got the balance right? Primary Science Review, 83, 17-19.

Harlen, W. (2013). Assessment \& inquiry-based science education: Issues in policy and practice. Global Network of Science Academies (IAP) Science Education Programme (SEP).

Hattie, J. A. C. (2009). Visible learning: A synthesis of over 800 meta-analyses relating to achievement. Routledge.

Hofstein, A., Navon, O., Kipnis, M., \& Mamlok-Naaman, R. (2005). Developing students' ability to ask more and better questions resulting from inquiry-type chemistry laboratories. Journal of Research in Science Teaching, 42(7), 791-806. https://doi. org/10.1002/tea.20072

Holloway, C. E. (2015). Teacher's level of inquiry-based chemistry and student's attitude about high school chemistry. [Doctoral dissertation, University of Alabama]. http://acumen.lib.ua.edu/content/u0015/0000001/0001811/u0015_0000001_0001811. pdf

Högström, P., Ottander, C., \& Benckert, S. (2010). Lab work and learning in secondary school chemistry: The importance of teacher and student interaction. Research in Science Education, 40(4), 505-523. https://doi.org/10.1007/s11165-009-9131-3 
Chang, C.-Y., \& Mao, S.-L. (1999). Comparison of Taiwan science students' outcomes with inquiry-group versus traditional instruction. Journal of Educational Research, 92(6), 340-346. https://doi.org/10.1080/00220679909597617

Kang, S. H. (2016). Spaced repetition promotes efficient and effective learning: Policy implications for instruction. Policy Insights from the Behavioral and Brain Sciences, 3(1), 12-19. https://doi.org/10.1177/2372732215624708

Khishfe, R., \& Abd-El-Khalick, F. (2002). Influence of explicit and reflective versus inquiry-oriented instruction on sixth graders' views of nature of science. Journal of Research in Science Teaching, 39(7), 551-578. https://doi.org/10.1002/tea.10036

Kireš, M., Ješková, Z., Ganajová, M., \& Kimáková, K. (2016). Bádatel'ské aktivity v prírodovednom vzdelávaní [Inquiry activities in science education]. Štátny pedagogický ústav (ŠPÚ).

Kirschner, P. A., Sweller, J., \& Clark, R. (2006). Why minimal guidance during instruction does not work: An analysis of the failure of constructivist, discovery, problem-based, experiential and inquiry-based teaching. Educational Psychologist, 41(2), 75-86. https://doi.org/10.1207/s15326985ep4102_1

Klahr, D., \& Nigam, M. (2004). The equivalence of learning paths in early science instruction: Effects of direct instruction and discovery learning. Psychological Science, 15(10), 661-667. https://doi.org/10.1111/j.0956-7976.2004.00737.x

Krajcik J., Mamlok R. \& Hug B., (2001). Modern content and the enterprise of science: science education in the 20th century. In L. Corno (Ed.), Education across a century: The centennial volume (pp. 205-238). National Society for the Study of Education (NSSE).

Laksana, D. N. L., Dasna, W. I., \& Degeng, N. S. I. (2019). The effects of inquiry-based learning and learning styles on primary school students' conceptual understanding in multimedia learning environment. Journal of Baltic Science Education, 18(1), 51-62. https://doi.org/10.33225/jbse/19.18.51

Lederman, N. G., Abell, S. \& Akerson, V. (2008). Students' knowledge and skills with inquiry. In E. Abrams, S. A. Southerland, \& P. Silva (Eds.), Inquiry in the classroom: Realities and opportunities (3-38). Information Age Publishing.

Lederman, J. S., Lederman, N. G., Bartos, S. A., Bartels, S. L., Antink-Meyer, A., \& Schwartz, R. S. (2014). Meaningful assessment of learners' understandings about scientific inquiry - The views about scientific inquiry (VASI) questionnaire. Journal of Research in Science Teaching, 51(1), 65-83. https://doi.org/10.1002/tea.21125

Lemlech, J. K. (1998). Curriculum and instruction methods for elementary and middle school. Prentice-Hall, Inc.

Levy, A. J., Minner, D. D, \& Jablonski, E. S. (2007, April 15-18). Inquiry-based science instruction and students' science content knowledge: A research synthesis. [Paper presentation]. National Association for Research in Science Teaching Annual Meeting. New Orleans, LA, USA.

Linn, M. C., Lee, H. S., Tinker, R., Husic, F., \& Chiu, J. L. (2006). Teaching and assessing knowledge integration in science. Science, 313(5790), 1049-1050. https://doi.org/10.1126/science.1131408

Llewellyn, D. (2002). Inquire within: Implementing inquiry-bases science standards. Corwin Press.

Llewellyn, D. (2013). Teaching high school science through inquiry and argumentation (2nd ed.). Corwin A Sage Company.

Marshall, J. C., \& Alston, D. M. (2014). Effective, sustained inquiry-based instruction promotes higher science proficiency among all groups: A 5-year analysis. Journal of Science Teacher Education, 25(7), 807-821. https://doi.org/10.1007/s10972-014-9401-4

Marshall, J. C., \& Horton, R. M. (2011). The relationship of teacher facilitated inquiry-based instruction to student higher-order thinking. School Science and Mathematics, 111(3), 93-101. https://doi.org/10.1111/j.1949-8594.2010.00066.x

Marshall, J. C., Smart, J. B., \& Alston, D. M. (2016). Inquiry-based instruction: a possible solution to improving student learning of both science concepts and scientific practices. International Journal of Science and Mathematics education, 25(7), 807-821. https://doi.org/10.1007/s10763-016-9718-x

Mayer, R. (2004). Should there be a three-strikes rule against pure discovery learning? The case for guided methods of instruction. American Psychologist, 59(1), 14-19. https://doi.org/10.1037/0003-066X.59.1.14

McLoughlin, E., Finlayson, O., \& van Kampen, P. (2012). Report on mapping the development of key skills and competencies onto skills developed in IBSE. SAILS project.

http://www.sails-project.eu/sites/default/files/outcomes/d1-1.pdf.

Miklovičová, J., Galabová, A., Valovič, J., \& Gondžúrová, K. (2017). PISA 2015: Národná správa Slovensko [PISA 2015: Slovakia national report]. Národný ústav certifikovaných meraní vzdelávania (NÚCEM). https://www.nucem.sk/dl/3482/NS_PISA_2015.pdf

Millar, R. \& Abrahams, I. (2009). Practical work: making it more effective. School Science Review, 91 (334), 59-64.

Minner D. D., Levy A. J., \& Century J. (2010). Inquiry-based science instruction - what is it and does it matter? Results from a research synthesis years 1984 to 2002. Journal of Research in Science Teaching, 47(4), 474-496. https://doi.org/10.1002/tea.20347

Montessori, M. (2017). Repetition and child development in Montessori Education. Montessori Academy. https://montessoriacademy.com.au/repetition-child-development-montessori/

National Research Council (NRC). 2000. Inquiry and the national science education standards: A guide for teaching and learning. National Academy Press.

Nieswandt, M. (2007). Student affect and conceptual understanding in learning chemistry. Journal of Research in Science Teaching, 44(7), 908-937. https://doi.org/10.1002/tea.20169

OECD. (2019). PISA 2018 Results (Volume I):What students know and can do. OECD Publishing. https://doi.org/10.1787/19963777

Oliveira, A. W. (2010). Engaging students in guided science inquiry discussions: Elementary teachers' oral strategies. Journal of Science Teacher Education, 21(7), 747-765. https://doi.org/10.1007/s10972-009-9168-1

Pandey, A., Nanda, G. K., \& Ranjan. V. (2011). Effectiveness of inquiry training model over conventional teaching method on academic achievement of science students in India. Journal of Innovative Research in Education, 1(1), 7-20.

Pellegrino, J. W., \& Hilton, M. L. (Eds.) (2012). Education for life and work: Developing transferable knowledge and skills in the 21st century. National Academies Press. 
Petlák, E. (2004). Všeobecná didaktika [General didactics]. Iris.

Piaget, J. (1973). Main Trends in Psychology. George Allen \& Unwin.

Prince, M., \& Felder, R. (2007). The many faces of inductive teaching and learning. Journal of College Science Teaching, 36(5), 14-20.

Rabčan, J., Rusnák, P., Zaitseva, E., Maceková, D., Kvassay, M., \& Sotáková, I. (2019). Analysis of Data Reliability based on Importance Analysis. In IDT 2019 Committees (Eds.), 2019 International Conference on Information and Digital Technologies (IDT) (pp. 402-408). Institute of Electrical and Electronics Engineers (IEEE). https://doi.org/10.1109/DT.2019.8813668

Rezba, R. J., Auldridge, T., \& Rhea, L. (1999). Teaching \& learning the basic science skills. Dept. of Education, Office of Elementary and Middle School Instructional Services. https://www.worldcat.org/title/teaching-learning-the-basic-science-skills/ oclc/49300200

Rocard, M., Csermely, P., Jorde, D., Walberg-Henriksson, H., \& Hemmo, V. (2007). Science education now: A renewed pedagogy for the future of Europe. European Communities.

Sadeh, I., \& Zion, M. (2009). The development of dynamic inquiry performances within an open inquiry setting: A comparison to guided inquiry setting. Journal of Research in Science Teaching, 46(10), 1137-1160. https://doi.org/10.1002/tea.20310

Sever, D., \& Güven, M. (2014). Effect of inquiry-based learning approach on student resistance in a science and technology course. Educational Science: Theory and Practice, 14(4), 1601-1605. https://doi.org/10.33225/jbse/19.18.51

Schneider, R. M., Krajcik, J., Marx, R. W., \& Soloway, E. (2002). Performance of students in project-based science classrooms on a national measure of science achievement. Journal of Research in Science Teaching, 39(5), 410-422. https://doi.org/10.1002/ tea.10029

Schroeder, C. M., Scott, T. P., Tolson, H., Huang, T. Y., \& Lee, U. H. (2007). A meta-analysis of national research: Effects of teaching strategies on student achievement in science in the United States. Journal of Research in Science Teaching, 44 (10), 14361460. https://doi.org/10.1002/tea.20212

Sotáková, l., Ganajová, M., \& Babinčáková, M. (2020). Implementation of the inquiry activity“Effect of the surface area on the rate of chemical reactions" in teaching at lower secondary school - findings from a questionnaire survey. In L. Gómez Chova, A. López Martínez, \& I. Candel Torres (Eds.), INTED 2020: 14th annual International Technology, Education and Development Conference (pp. 4668-4676). IATED Academy. http://dx.doi.org/10.21125/inted.2020.1291

SPSS Inc. (2009). PASW statistics for Windows, Version 18.0. SPSS.

Škoda, J., Doulík, P., Bílek, M., \& Šimonová, I. (2015). The effectiveness of inquiry based science education in relation to the learners' motivation types. Journal of Baltic Science Education, 14(6), 791-803. http://www.scientiasocialis.It/jbse/?q=node/472

ŠPÚ. (2014). ŠVP ISCED 2 - Štátny vzdelávací program pre nižšie stredné vzdelávanie, Vzdelávacia oblast: Človek a príroda, Chémia [The National Education Programme for Lower Secondary Education, Education Area: Man and Nature, Chemistry]. http:// www.statpedu.sk/files/articles/dokumenty/inovovany-statny-vzdelavaci-program/chemia_nsv_2014.pdf

Trna, J., Trnová, E., \& Svobodova, J. (2012). Inquiry-based science education experiments. In C. Bolte, J. Holbrook, \& F. Rauch (Eds.), Inquiry-based science education in Europe: Reflections from the PROFILES project (pp. 212-215). Freie Universitat Berlin. https://pdfs.semanticscholar.org/d06e/d51311789175dc4c9d17fc189e9358c9c6d0.pdf

Vicenová, H., \& Ganajová, M. (2019). Metodická príručka k učebnici chémie pre 7. ročník ZŠ a 2. ročník gymnázia s osemročným štúdiom [The methodology guide for teaching chemistry in the 7th grade of secondary schools and 2th year of 8-year grammar schools]. Expol pedagogika.

Von Secker, C. E., \& Lissitz, R. W. (1999). Estimating the impact of instructional practices on student achievement in science. Journal of Research in Science Teaching, 36(10), 1110-1126. https://doi.org/10.1002/(SICI)1098-2736(199912)36:10<1110::AIDTEA4>3.0.CO;2-T

Walker, M. (2007). Teaching inquiry-based science: A guide for middle and high school teachers. Lightning Source.

Wallace, C. S., \& Kang, N. H. (2004). An investigation of experienced secondary science teachers' beliefs about inquiry: An examination of competing belief sets. Journal of Research in Science Teaching, 41(9), 936-960. https://doi.org/10.1002/tea.20032

Wang, P. H., Wu, P. L., Yu, K. W., \& Lin, Y. X. (2015). Influence of implementing inquiry-based instruction on science learning motivation and interest: A perspective of comparison. Procedia Social and Behavioral Sciences, 174, 1292-1299. https://doi. org/10.1016/j.sbspro.2015.01.750

White, B. Y., \& Frederiksen, J. R. (1998). Inquiry, modeling, and metacognition: Making science accessible to all students. Cognition and Instruction, 16(1), 3-118. https://doi.org/10.1207/s1532690xci1601_2

Wilcox, J., Kruse, J. W., \& Clough, M. P. (2015). Teaching science through inquiry: Seven common myths about this time-honored approach. The Science Teacher, 82(6), 62-67.

William P. B., Barstack, R., Clark, D., Hull, E., Goodman, B., Judy Kook, J., Kraft, K., Ramakrishna, P., Roberts, E., Shaw, J., Weaver, D., \& Michael Lang, M. (2008). Writing-to-learn in the inquiry-science classroom: Effective strategies from middle school science and writing teachers, The Clearing House: A Journal of Educational Strategies, Issues and Ideas, 81(3), 105-108. https://doi. org/10.3200/TCHS.81.3.105-108

Windschitl, M. (2002). Inquiry projects in science teacher education: What can investigative experiences reveal about teacher thinking and eventual classroom practice? Science Education, 87(1), 112-143. https://doi.org/10.1002/sce.10044

Witt, C., \& Ulmer, J. (2010, April 21-24). The impact of inquiry-based learning on the academic achievement of middle school students [Conference session]. Western Region AAAE Research Conference, Great Falls, MT, United States. http://aaaeonline. org/Resources/Documents/Western\%20Region/Conference\%20Proceedings,\%20Western\%202010.pdf

Zoller, U. (2011). Science and technology education in the STES context in primary schools: What should it take? Journal of Science Education and Technology, 20(5), 444-453.

https://doi.org/10.1007/s10956-011-9306-3 


\section{Appendix}

\section{A. "Changes in chemical reactions" thematic unit: description of confirmation inquiry activities}

\begin{tabular}{|c|}
\hline Inquiry activity \\
\hline 1 Exothermic and endothermic reactions \\
\hline $\begin{array}{l}\text { The activity focuses on exothermic and endothermic reactions. Students investigate the thermal changes in chemical reactions of vinegar } \\
\text { with sodium bicarbonate vs. sodium bicarbonate (solution) with calcium chloride. They enhance their knowledge of exothermic and endo- } \\
\text { thermic reactions by learning about their practical use (self-heating or cooling sachets, self-heating cans). }\end{array}$ \\
\hline $\begin{array}{l}\text { Factors affecting the rate of chemical reactions } \\
2 \text { The effect of concentration on the rate of chemical reactions } \\
3 \text { The effect of temperature on the rate of chemical reactions } \\
4 \text { The effect of surface area on the rate of chemical reactions }\end{array}$ \\
\hline $\begin{array}{l}\text { The goal of the activity is to verify the effect of various factors on the reaction rate between vinegar and sodium bicarbonate in practice. } \\
\text { Students observe the course of this chemical reaction using simple apparatus (flask with a balloon on its neck). The chemical reaction rate } \\
\text { is affected for example by diluting vinegar, increasing its temperature, or crushing the sodium bicarbonate tablet. These factors affect the } \\
\text { speed with which the balloon is inflated by the released carbon dioxide. Students apply this knowledge to explain real-life situations such as } \\
\text { setting fire, food storage methods, or kettle limescale removal. }\end{array}$ \\
\hline 5 The effect of catalysts on the rate of chemical reactions \\
\hline $\begin{array}{l}\text { This activity focuses on catalysts. Students verify how the presence of ash or sand affect how a sugar cube burns in practice. They enhance } \\
\text { their knowledge about caramelisation and the function of catalytic converters in cars. They also learn about the lactase enzyme and its role } \\
\text { in lactose digestion (milk sugar) and the reasons why lactose intolerance can emerge. }\end{array}$ \\
\hline
\end{tabular}

Ivana Sotáková (Corresponding author)

Mária Ganajová

Mária Babinčáková
PhD., Lecturer, Pavol Jozef Šafárik University in Košice, Faculty of Science, Department of Didactics of Chemistry, Šrobarová 2, Košice, Slovakia. E-mail: ivana.sotakova@upjs.sk ORCID: https://orcid.org/0000-0002-8910-5786

Assoc. Prof., Assistant Professor, Pavol Jozef Šafárik University in Košice, Faculty of Science, Department of Didactics of Chemistry, Šrobarová 2, Košice, Slovakia E-mail: maria.ganajova@upjs.sk

MS, PhD Student, Pavol Jozef Šafárik University in Košice, Faculty of Science, Department of Didactics of Chemistry, Šrobarová 2, Košice, Slovakia.

Charles University in Prague, Faculty of Science, Department of Teaching and Didactics of Chemistry, Albertov 6, Praha 2, Czech Republic.

E-mail: maria.babincakova@upjs.sk

ORCID: https://orcid.org/0000-0003-2365-8545 